\title{
ISOLATION AND STRUCTURE DETERMINATION OF ANTICANCER SUBSTANCES FROM MARINE MICROORGANISMS: A PRELIMINARY STUDY OF NEW BUTENOLIDE AS NEW ANTICANCER
}

\author{
Ariani Hatmanti ${ }^{1, *}$ and Kaneo Kanoh ${ }^{2}$ \\ ${ }^{1}$ Research Centre for Oceanography, Indonesian Institute of Sciences \\ Jl. Pasir Putih 1, Ancol Timur, Jakarta. 11048, Indonesia \\ ${ }^{2}$ Marine Biotechnology Institute, 3-75-1, Heita, Kamaishi-shi, Iwate, 026-0001, Japan \\ e-mail: arianihatmanti@yahoo.com
}

\begin{abstract}
An investigation to find new anticancer substances from marine microorganisms was conducted at the Marine Biotechnology Institute, Kamaishi Campus, Iwate, Japan. The samples were from MBI microorganism collection. They were bacteria, actinomycetes and fungus. Mammalian cancer cells, A549, were used as screening medium. The method for screening of the targeted microorganism was micro plate method. HK294 was found as microorganism which has the most interesting phenomenon in inhibiting A549 cancer cells. HK294 was identified to be Streptomyces viridocyaneus (homology $99 \%$ ) by its $16 \mathrm{~S}$ rDNA sequence. The HK294 was cultured in Marine Broth medium and incubated at $30^{\circ} \mathrm{C}$ for seven days in $100 \mathrm{rpm}$ orbital shaker incubator, to produce active substance. Silica Gel Column Chromatography and High Pressure Liquid Chromatography were used for separation of the active substances. NMR and Mass Spectrum were used for determination of the active substances. Butenolide, Teleocidin Al and New Butenolide were isolated from this experiment. The New Butenolide is promising to be used for anticancer drug but it need further research.
\end{abstract}

Keywords: Butenolide, New butenolide, Anticancer, Streptomyces viridocyaneus

\section{INTRODUCTION}

Cancer cells are cells that grow out of control. Unlike normal cells, cancer cells ignore signals to stop dividing, to specialize, or to die and be shed. Growing in an uncontrollable manner and unable to recognize their own natural boundary, the cancer cells may spread to areas of the body where they do not belong. It is difficult to find out sooner that a person got cancer, because the pain is not felt until the cancer become serious and difficult to treat. Cancer can be treated by medicinal drugs, but the problem is that the medicine is very expensive. This is because the material for drug production is limited. Presently, the drug for treating cancer that goes directly to the cancer cells have not been found yet. The drug that are used in cancer treatment are only for reducing the pain.
Paclitaxel is the good example to illustrate how expensive is the drug for cancer.Paclitaxel is a drug for breast, ovarium and lung cancer. It was produced from a plant called Taxus baccata, through its wood skin extraction since 1970, in America (Zhang et al., 2007). By the semi synthesis process, whole wood of one Taxus tree can only produced $1.3 \mathrm{mg}$ paclitaxel, one dose of one cancer patient in one time so it is very expensive. Since 1989, Samyang, Korean chemical company could produced Taxus chinensis by massive cells culture, and since 1995, it could be used for paclitaxel material sources. The cost then decreased for which Samyang Co., got ISO 9002 certificate in 1999. This techniques produces the source for Paclitaxel which is cheaper, environmentally friendly, and much more pure.

Terrestrial material for producing anticancer substance have been well explored. On the other hand, only less then $1 \%$ of marine species have been screened for organisms that contain or excrete novel compounds. It is hoped that the 
marine species could become the source for new anticancer drug. Due to that reason, this research was carried out to find new active substances out of marine bacteria, fungi and actinomycetes. This research was done in the Marine Biotechnology Institute, Kamaishi, Iwate, Japan.

\section{MATERIALS AND METHODS}

\section{Screening, Microplate Method}

The 96 wells microplates were used as method for screening the anticancer producing microorganisms. The A549 cells were subcultured in new bottle then about $4 \times 10^{4}$ cells $/ \mathrm{ml}$ was prepared in the 96 wells microplates. The subcultured cells were incubated for 24 hours in $\mathrm{CO}_{2}$ incubator. The $5 \mathrm{ml}$ of samples were added to each well, then incubated for 48 hours in $\mathrm{CO}_{2}$ incubator. About $10 \mathrm{ml}$ of alamar blue was added to each well and the plate was incubated for 4 hours in $\mathrm{CO}_{2}$ incubator. Microplates were then read on the microplate reader and the cells were observed under the microscope.

\section{Culture of HK294}

HK294 was stored on Marine Agar, consisting of Marine Broth 2216 Difco 37.4 gram, Bacto Agar 15 gram, distilled water $500 \mathrm{ml}$ and seawater 500 $\mathrm{ml}$ at $30^{\circ} \mathrm{C}$. The HK294 was cultured to produce active substances by Marine Broth medium and incubated at $30^{\circ} \mathrm{C}$ for seven days in $100 \mathrm{rpm}$ orbital shaker incubator. Then it was centrifuged at 5,000 $\mathrm{rpm}, 4^{\circ} \mathrm{C}$ for 30 minutes. Pellet was extracted for

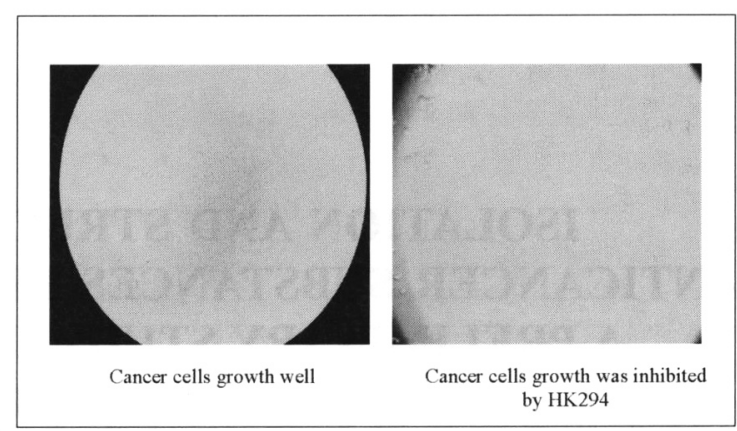

Figure 1. The comparison between the growth of A549 mammalian cancer cells in normal condition and under inhibition of HK294.

overnight using acetone, and the supernatant was extracted using ethyl acetate.

\section{Purification and Structure Determination}

High Pressure Liquid Chromathography was used for purification of the active substances. The NMR "Varian Inova 750" and Mass Spectrum "JEOL" was used for structure determination of the active substance.

\section{RESULTS AND DISCUSSION}

\section{Screening (Microplate Method)}

Over 1401 samples had been screened, including bacteria, fungus, and actinomycetes, about $4 \%$ had inhibiting activity to A549 cells. The result of screening was shown in Table 1 . The activity of inhibition to A549 cells was shown as "least growth" of A549 cancer cells compared to the blanc. The activity of active substance was

Table 1. The screening result of marine microorganisms tested to A549 mammalian cancer cells.

\begin{tabular}{|l|l|c|c|}
\hline \multicolumn{1}{|c|}{ Sample } & \multicolumn{1}{|c|}{ Variety } & Number of Samples & $\begin{array}{c}\text { Number of active } \\
\text { samples }\end{array}$ \\
\hline YM6 Samples & $\begin{array}{l}\text { Marine Bacteria, Fungi and } \\
\text { Actinomycetes }\end{array}$ & 160 & 25 \\
\hline $\begin{array}{l}\text { Kasai } \\
\text { Samples }\end{array}$ & $\begin{array}{l}\text { Marine Bacteria, Fungi and } \\
\text { Actinomycetes }\end{array}$ & 228 & 7 \\
\hline Hirose Samples & $\begin{array}{l}\text { Marine Bacteria, Fungi and } \\
\text { Actinomycetes }\end{array}$ & 127 & 10 \\
\hline Adachi Samples & $\begin{array}{l}\text { Marine Bacteria, Fungi and } \\
\text { Actinomycetes }\end{array}$ & 800 & 12 \\
\hline AR Samples & $\begin{array}{l}\text { Marine Bacteria cultured on Marine } \\
\text { Broth medium }\end{array}$ & 86 & 82 \\
\hline & Total Sample & 1401 & 6 \\
\hline
\end{tabular}


also shown under microscope as "abnormal growth" of A549 cells compare to the control. The shape of cancer cells which was inhibited by active substance could be seen as "round shape" cells or "needle fit" shape cells. It could also be "necrosis, strong necrosis, cytotoxic and mitotic inhibition". Figure 1 shows the comparison between normal growth of A549 cancer cells and inhibited growth of A549 cancer cells caused by active substance from marine microorganisms. Cancer cells growth was observed under the microscope. The inhibited growth of A549 cancer cells showed various forms. If the growth was inhibited as usual, it would not be chosen as the target. The targeted samples were chosen if cells were all dead and the shapes were strong necrosis, or "interested (beyond usual)". These criteria were used to minimize the number of samples which can be selected as the candidate to produce anticancer substance. Figure 2 shows the form of
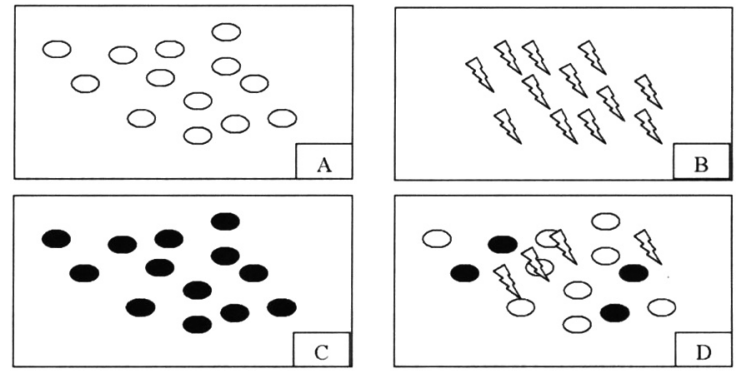

Figure 2. The form of inhibited growth of A549 cancer cells which were picked up as the target to produce active substance.

inhibited growth of A549 cancer cells which were picked up as the target to produce active substance.

\section{Culture of HK294 (Streptomyces viridocyaneus)}

HK294 which was isolated by Dr. Shu Ishikawa from Kamaishi Bay, was identified to be Streptomyces viridocyaneus (homology $99 \%$ ) by its 16 s rDNA sequence. The $S$. viridocyaneus was stored on Marine Agar (Marine Broth 2216 Difco 37.4 gram, Difco Bacto Agar 15 gram and Distilled Water $500 \mathrm{ml}$ and seawater $500 \mathrm{ml}$ ) at $30^{\circ} \mathrm{C}$. Figure 3 shows the growth of $S$. viridocyaneus on the Marine Agar plate and Marine Broth medium. The $S$. viridocyaneus was cultured to produce the active substance in 10 liters of Marine Broth which was kept at $30^{\circ} \mathrm{C}$ and shook $100 \mathrm{rpm}$ in shaker incubator for 7 days. Then it was centrifuged at $5,000 \mathrm{rpm}, 4^{\circ} \mathrm{C}$ for 30 minutes. Pellet was extracted for overnight by acetone, and the supernatant was extracted by ethyl acetate. Targeted substance was found in both pellet and supernatant extract.

\section{Purification and Structure Determination}

Positive activity was found in ethyl acetate layer of supernatant $(97.9 \mathrm{mg})$ and acetone layer of cells mass pellet $(104.7 \mathrm{mg}$ ). The A549 cancer cells was fully inhibited and showed as "interested" shape by both of ethyl acetate layer and acetone layer. The layers were then fractioned using silica gel column chromatography.

\section{Ethyl acetate Layer of Supernatant}

The active sample as ethyl acetate extract (97.9 mg) was loaded on silica gel column Wako gel C-300,10 g, then eluted by step manner with $\mathrm{CHCl}_{3}, \mathrm{CHCl}_{3} / \mathrm{Methanol}$ (100:1), $\mathrm{CHCl}_{3} / \mathrm{Methanol}$ (10:1), and finally with Methanol. The active substances was found in Chloroform $\left(\mathrm{CHCl}_{3}\right)$ and $\mathrm{CHCl}_{3}$ : Methanol (100:1) part. Each of parts was then first purified by High Pressure Liquid Chromatography (HPLC) on $210 \mathrm{~nm}$ spectrum.

The active substances in Chloroform part (46.6 $\mathrm{mg}$ ) were found in three fractions, fraction $20^{\text {th }}$, fraction $18^{\text {th }}$ and fraction $6^{\text {th }}$. The active substance in fraction $18^{\text {th }}$ was more powerful than that in fraction $6^{\text {th }}$, but the shape of A549 cells were the same namely as round shape cells. The structure of active substance in the fractions were then determined by NMR "Varian Inova 750" and Mass Spectrum "JEOL". The active substance in fraction $6^{\text {th }}$ was determined as Butenolide with the molecular formula as $\mathrm{C}_{13} \mathrm{H}_{22} \mathrm{O}_{3}$. This Butenolide is known for having antifungal activity. The active substance in fraction $20^{\text {th }}$ was determined as Teleocidin-A1 with the molecular formula as $\mathrm{C}_{27} \mathrm{H}_{39} \mathrm{~N}_{3} \mathrm{O}_{2}$. Teleocidin-A1 is known as a cancer promoter besides as a cancer cells inhibitor. The active substance in fraction $18^{\text {th }}$ was determined as New Butenolide with the molecular formula $\mathrm{C}_{13} \mathrm{H}_{22} \mathrm{O}_{2}$ and was known for having anticancer activity. The New Butenolide is promising for being an anticancer drug in the near future, though need further research works.

The active substance in $\mathrm{CHCl}_{3}$ : Methanol $(100: 1)$ parts $(83.8 \mathrm{mg})$ was found in fraction $20^{\text {th }}$. The shape of the cancer cells was round shape cells. The structure of active substance in frac- 
tion $20^{\text {th }}$ was then determined by NMR "Varian Inova 750" and Mass Spectrum "JEOL". It was determined as Teleocidin-A1 with the molecular formula as $\mathrm{C}_{27} \mathrm{H}_{39} \mathrm{~N}_{3} \mathrm{O}_{2}$. It is the same as the active substance in fraction $20^{\text {th }}$ of Chloroform part

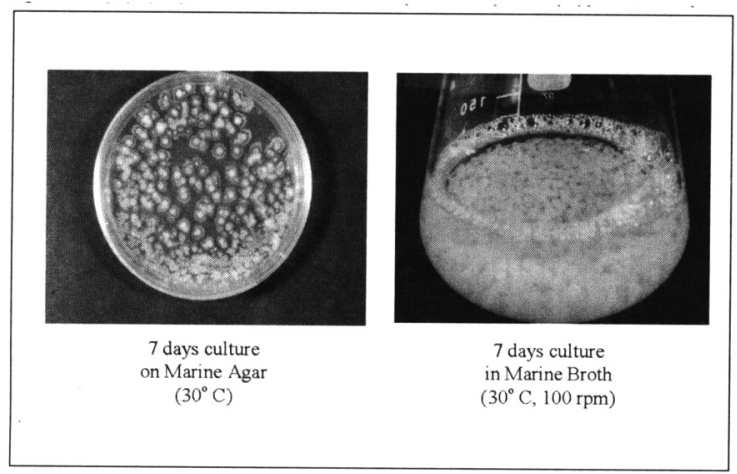

Figure 3. Performance of HK294 or Streptomyces viridocyaneus in Marine Agar and Marine Broth Media.

cancer promoter and a cancer cells inhibitor, depending on its amount.

\section{Acetone Layer of Cells Mass Pellet}

The active substances in cells mass pellet (104.7 mg) was loaded in Silica Gel Column Chromatography (Wako gel C-300, 10 g), then eluted by step manner with $\mathrm{CHCl}_{3}, \mathrm{CHCl}_{3} /$ Methanol (100:1), $\mathrm{CHCl}_{3} /$ Methanol (10:1), and finally with Methanol. The active substances were found in Chloroform $\left(\mathrm{CHCl}_{3}\right)$ and $\mathrm{CHCl}_{3}$ : Methanol (100:1) fraction. Each of fractions then was purified using High Pressure Liquid Chromatography (HPLC) on $210 \mathrm{~nm}$ spectrum.

The substance in Chloroform part $(64.3 \mathrm{mg})$ was loaded in HPLC and the active substance was not found. The cell shapes were not so interesting, and there were no round shape cells on it.

The active substance in $\mathrm{CHCl}_{3}$ : Methanol $(100: 1)$ parts $(20.9 \mathrm{mg})$ was found in fraction $19^{\text {th. }}$ The shape of the cancer cells observed under the microscope was round shape cells. The structure of active substance in fraction $19^{\text {th }}$ was then determined by NMR "Varian Inova 750" and Mass Spectrum "JEOL". It was determined as Teleocidin-A1 with the molecular formula as $\mathrm{C}_{27} \mathrm{H}_{39} \mathrm{~N}_{3} \mathrm{O}_{2}$. It is similar with active substance in fraction $19^{\text {th }}$ of Chloroform part of HK294 Supernatant.

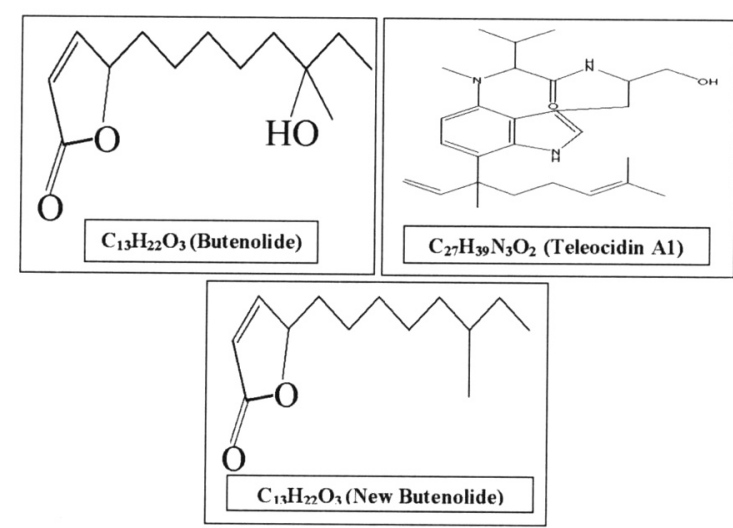

Figure 4. The molecular formula of Butenolide, Teleocidin-A1, and New Butenolide.

The molecular formula of Butenolide, New Butenolide and Teleocidin-A1 are shown in Figure 4,5 and 6.

\section{CONCLUSION}

Three anticancer substances have been successfully isolated during the experiment. They are Butenolide, teleocidin A-1 and New Butenolide. The latest is potentially promising as an anticancer substance.

Acknowledgements. We would like to thank the Japan International Coorporation Agency (JICA) especially Tohoku Branch, for financial assistance to the research programme. Many thanks to Dr. Kaneo Kanoh, Dr. Yoshikazu Shizuri, Dr. Kyoko Adachi, Prof. Mamoru Endo of the Marine Biotechnology Institute for the conduction and guidance during the research works. Also great appreciation to Mr. Toshio Nakamura, the Training Coordinator, who always gave his advice and help for doing the research experiment.

\section{REFERENCES}

Adachi, K., K. Kanoh, P. Wisespongp, M. Nishijima, and Y. Shizuri. 2005. Clonostachysins A and B, New Anti-dinoflagellate Cyclic Peptides from a Marine-derived Fungus. J. Antibiot., 58(2): 145-150.

Improved paclitaxel accumulation in cell suspension cultures of Taxus chinensis by brassinolide. http:/ /www.springerlink.com/content/t27r2r38g6r55521/, November, $3^{\text {rd }} 2004$.

Irie, K., S. Kajiyama, S. Okuno, M. Kondo, and K. Koshimizu. 1994. New Teleocidin-Related Metabo- 
lites, (-)-7-Geranylindolactam-V and Blastmycetin F, from Streptoverticillium blastmyceticum. Journal of Natural Products, 57(3): 363-368.

Matsuo Y., K. Kanoh, T. Yamori, H. Kasai, A. Katsuta, K. Adachi, K. Shin-Ya, and Y. Shizuri. 2007. Urukthapelstatin A, a Novel Cytotoxic Substance from Marine-derived Mechercharimyces asporophorigenens YM11-542. J. Antibiot., 60(4): 251-255.
Subramanian, B., A. Nakeff, K. Tenney, P. Crews , L. Gunatilaka, and F. Valeriote. 2006. A new paradigm for the development of anticancer agents from natural products. J. Exp. Ther. Oncol., 5(3):195-204.

Zhang, C. H., P. S. Fevereiro, G. He and Z. Chen. 2007. Paclitaxel production and extracellular release of Taxus chinensis cell suspension cultures adapted to Chitosan. Plant Science, 172 (1): 158-163. 